\title{
SANGKULUS (Sangkep, Ngatag, dan Kulkul Bulus) OPTIMALISASI KOMUNIKASI BERBASIS KEARIFAN MENYAMA BERAYA DALAM MITIGASI BENCANA GUNUNG AGUNG
}

\author{
I Gusti Ayu Agung Putri Utami ${ }^{1)}$ \\ 1) SMKN 1 Abang, Karangasem \\ *) Email : agungputri@gmail.com
}

\begin{abstract}
Abstrak
Penelitian ini dilaksanakan di Kawasan Gunung Agung dengan tujuan yaitu (1) Mendeskripsikan kondisi fisik dan historis Gunung Agung (2) mendeskripsikan kearifan lokal masyarakat Karangasem dan kaitannnya dengan mitigasi bencana, (3) mendeskripsikan persepsi dan sistem komunikasi masyarakat Karangasem mengenai bencana dan mitigasi bencana erupsi Gunung Agung, dan (4) mendeskripsikan optimalisasi komunikasi berbasis kearifan lokal menyama beraya dengan sistem sangkulus dalam upaya mitigasi bencana gunung Agung. Penelitian ini merupakan jenis penelitian kualitatif. Penelitian ini merupakan penelitian kualitatif. Teknik pengumpulan data dalam penulisan karya ilmiah ini yaitu dengan wawancara, observasi/dokumentasi, dan telaah pustaka. Data yang diperoleh dari beberapa hasil wawancara dan observasi dengan dipadukan kajian pustaka, kemudian dianalisis secara deskriptif kualitatif. Hasil dari penelitian ini yaitu 1) Gunung Agung tergolong gunung api tipe stratovulcano berbentuk kerucut dengan kawah memanjang terbuka berukuran $625 \mathrm{~m}$ x $425 \mathrm{~m}$. 2) Masyarakat Karangasem memiliki kearifan lokal terkait dengan bencana erupsi gunung Agung dilihat dari empat sisi. 3) Persepsi masyarakat terhadap bencana beraneka ragam. 4) Optimalisasi komunikasi berbasis kearifan lokal dalam upaya mitigasi bencana erupsi gunung Agung dapat ditinjau dari tiga (3) sistem komunikasi yang disebut sangkulus, yaitu Sangkep, Ngatag, Kulkul Bulus..
\end{abstract}

Kata-Kata Kunci: Kearifan Lokal, Mitigasi Bencana, Gunungapi

\begin{abstract}
The study was conducted in Gunung Agung area with the aim of (1) Describing the physical and historical condition of Gunung Agung (2) describing the local wisdom of Karangasem community and its relation with disaster mitigation, (3) describing perception and communication system of Karangasem community about disaster and eruption disaster mitigation Gunung Agung, and (4) to describe the optimization of local wisdom-based communications equally rich with sangkulus system in the effort of mitigation of Gunung Agung disaster. This research is a type of qualitative research. This research is a qualitative research. Data collection techniques in the writing of this scientific paper is by interview, observation / documentation, and literature review. Data obtained from several interviews and observations with the combined literature review, and then analyzed descriptively qualitative. The results of this study are 1) Mount Agung
\end{abstract}


classified stratovulcano cone-shaped volcano type with an open elongated crater measuring $625 \mathrm{~m} \times 425 \mathrm{~m}$. 2) The community of Karangasem has local wisdom related to the eruption of Mount Agung disaster is seen from four sides. 3) People's perception of disaster is diverse. 4) Optimization of local wisdom-based communication in disaster mitigation efforts Agung eruption eruption can be viewed from three (3) communication system called sangkulus, namely Sangkep, Ngatag, Kulkul Bulus..

Keywords: Local Wisdom, Disaster Mitigation, Volcanic

\section{PENDAHULUAN}

kecamatan

Gunung Agung terletak di

Karangasem, tepatnya pada posisi 8020,5'LS dan 115030,5'BT dengan ketinggian $3142 \mathrm{~m}$ dari permukaan laut. Gunung Agung merupakan gunung api tipe stratovulcano yang berbentuk kerucut dengan kawah memanjang terbuka dan dengan ukuran $625 \mathrm{~m} \times 425 \mathrm{~m}$ (Pratomo, 2006). Gunung ini tergolong gunung aktif dan memiliki sejarah letusan yang sangat dahsyat pada tahun 1963, mengakibatkan jatuhnya korban jiwa sebanyak 1.148 meninggal dunia dan 296 luka-luka (Kusumadinata; 1979).

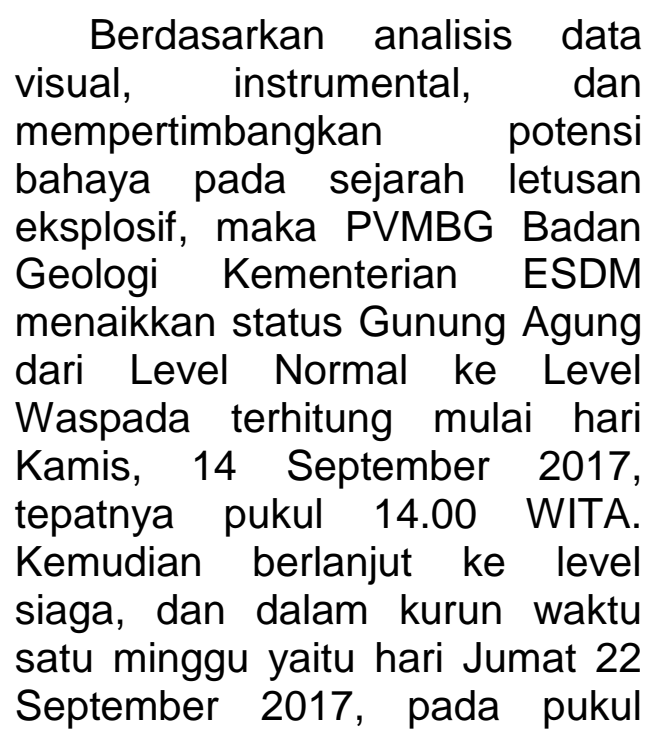

21.30 WITA, Gunung Agung dinyatakan berada dalam level Awas (Nusabali.com, 2017).

Fakta bahwa eskalasi gunung Agung sangat cepat ke level awas, membuat masyarakat Karangasem menjadi resah. Terjadi kemacetan jalur Karangasem - Denpasar mulai pukul 23.30 WITA karena kepanikan masyarakat yang berbondong-bondong

meninggalkan kota Amlapura (Balipost.com,2017). Kepanikan terjadi akibat simpang siurnya berita mengenai prediksi waktu letusan gunung Agung yang menyebar dari mulut ke mulut. Apabila ditelusuri, menurut kepala PVMBG, rekomendasi yang dikeluarkan oleh Badan Geologi untuk level awas, yaitu masyarakat di sekitar gunung dan pengunjung agar tidak beraktivitas di dalam area kawah dan dilakukan sterilisasi bertahap pada kawasan $9 \mathrm{~km}$ dari bibir kawah Gunung Agung serta diperluas untuk sektoral arah utara timur laut, tenggara, dan barat daya, sejauh $12 \mathrm{~km}$. Hal ini berarti masyarakat di kota Amlapura (Kawasan Rawan Bencana / KRB 1) masih cukup aman kecuali jika erupsi telah terjadi disertai hujan deras. 
Namun keresahan masyarakat yang memuncak mengakibatkan masyarakat mudah terprovokasi dan tidak bisa bekerja sama dengan para aparat.

Penyebab utama dari kepanikan masyarakat berawal dari kurangnya pengetahuan tentang bencana dan mitigasi bencana. Survei yang dilakukan Litbang Kompas di Karangasem pada Juli 2011 memperlihatkan $51 \%$ warga di lereng gunung Agung tidak mengetahui bahwa wilayah tinggalnya adalah daerah rawan bencana (Kompas.com, 2011). Sementara itu, berdasarkan hasil wawancara penulis dengan 30 narasumber yang terdiri dari warga sekolah, pengungsi, dan masyarakat di sekitar penulis, tanggal 27-28 September 2017, 80\% diantaranya tidak paham apa makna dari istilah KRB. Salah seorang narasumber di zona awas (wilayah Kesimpar) menyebutkan yakin wilayahnya aman, sedangkan narasumber lain dari KRB 1 (wilayah Sibetan) justru memilih mengungsi dini karena khawatir. Selain itu, 60\% diantara narasumber selain pengungsi mengaku belum mempersiapkan langkah antisipasi apapun untuk menghadapi bencana. Faktafakta tersebut menunjukkan kurang optimalnya sosialisasi pemerintah, informasi belum tersebar merata ke seluruh lapisan masyarakat sehingga timbul ketidaksepahaman persepsi dan tanggapan terhadap bencana.
Upaya menangani bencana sejak dini (mitigasi pra-bencana) tidak dapat terlepas dari komunikasi yang baik dengan masyarakat. Mitigasi bencana sebaiknya diintegrasikan dengan kearifan lokal masyarakat itu sendiri. Menurut sebuah penelitian tentang gunung Sinabung (dalam Lestari, dkk., 2015) proses perancangan komunikasi lingkungan yang strategis di daerah rawan bencana, memerlukan bimbingan teknis dari pemerintah yang bekerja sama dengan pemangku atau tokoh daerah setempat dan menggunakan sarana komunikasi yang tepat. Masyarakat Karangasem masih memegang teguh tradisi lokal, sehingga diperlukan sarana komunikasi dan cara penyampaian informasi yang merakyat.

Masyarakat memiliki kearifan yang disebut menyama beraya atau pola bermasyarakat yang kompak dalam menyelesaikan suatu permasalahan bersamasama, tanpa harus bergantung pada pemerintah saja. Mitigasi bencana erupsi gunung Agung yang terbukti efektif dilakukan masyarakat Bali dengan konsep menyama beraya, diantaranya adalah langkah pemberian bantuan pada para pengungsi secara mandiri oleh masyarakat Bali melalui ngamen masal dan sumbangan sukarela (yadnya) lainnya. Hal ini diakui oleh ketua BNPN yang dilansir dalam berita harian Nasional Kompas (25 September 2017), bahwa budaya menyama braya masyarakat Bali sangat patut diacungi jempol. 
Konsep ini dapat diadaptasi dalam menjembatani penyaluran informasi dari pemerintah ke segenap lapisan masyarakat. Alur komunikasi sebaiknya dimulai dengan penjelasan informasi tentang bencana, pengenalan kawasan rawan bencana, dampak bencana, dan langkah mitigasi bencana dari perwakilan pemerintah (petugas penanggulangan bencana) kepada tokoh masyarakat (ketua desa), ketua desa meneruskan kepada ketua banjar/dadia/klan dan ketua sekeha teruna atau pemuda, melalui kegiatan sangkep atau rapat adat. Hasil sangkep disosialisasikan melalui sistem ngatag atau pengumuman langsung ke rumah-rumah. Selain itu, kesepakatan tentang penggunaan sarana komunikasi tradisional seperti kulkul bulus (kentongan yang diketuk dengan frekuensi cepat) sebagai tanda peringatan dini saat keadaan darurat, juga perlu disosialisasikan kembali. Penyampaian informasi yang detail, dengan melibatkan peran tokoh masyarakat yang disegani, serta penggunaan bahasa daerah dan alat komunikasi tradisional, akan menciptakan keterbukaan pemikiran masyarakat untuk lebih kompak dalam menanggapi dan mengantisipasi bencana, sehingga memudahkan proses mitigasi. Berdasarkan uraian yang dipaparkan adapun tujuan penelitian ini yaitu 1) mendeskripsikan kondisi fisik dan historis Gunung Agung; 2) memaparkan kearifan lokal masyarakat Karangasem dan kaitannnya dengan mitigasi bencana; 3) memaparkan persepsi dan sistem komunikasi masyarakat Karangasem mengenai bencana dan mitigasi bencana erupsi Gunung Agung; menguraikan optimalisasi komunikasi berbasis kearifan lokal menyama beraya dengan sangkulus dalam upaya mitigasi bencana gunung Agung.

\section{METODE}

Penulisan karya ilmiah ini merupakan jenis penelitian kualitatif. Teknik pengumpulan data dalam penulisan karya ilmiah ini yaitu dengan wawancara,

observasi/dokumentasi, dan telaah pustaka. Data yang diperoleh dari beberapa hasil wawancara dan observasi dengan dipadukan kajian pustaka, kemudian dianalisis secara deskriptif kualitatif dengan mencari keterkaitan dari datadata tersebut yang sesuai dengan materi yang dikaji.

\section{HASIL DAN PEMBAHASAN}

\section{Kearifan Lokal Masyarakat Karangasem dalam Mitigasi Bencana}

Berdasarkan hasil wawancara dengan tokoh masyarakat, masyarakat saksi letusan gunung Agung pada tahun 1963, masyarakat terdampak, dan para pengungsi, dapat dipaparkan mengenai kearifan lokal masyarakat Karangasem berkaitan dengan mitigasi bencana ditinjau dari aspek pengetahuan, kepercayaan, 
langkah pencegahan, dan sarana komunikasi.

\section{Sisi pengetahuan tradisional}

Selama ini masyarakat telah memiliki pengetahuan tentang bagaimana kronologis, bahaya, dampak, dan daerah terdampak jika gunung Agung mengalami erupsi. Pengetahuan ini diperoleh dari cerita para orang tua yang telah mengalami kejadian tersebut pada tahun 1963. Berdasarkan cerita inilah masyarakat dapat mengklaim daerahnya aman atau tidak sebelum adanya informasi dari badan PVMBG. Masyarakat sudah memiliki pengetahuan secara geografis dalam hal lokasi tempat tinggalnya yang dekat dengan bukit akan aman dari loncatan batu pijar, dan termasuk di daerah tinggi akan aman dari lahar, sedangkan yang berbahaya adalah di daerah seputaran gunung Agung karena ancaman lahar panas dan daerah-daerah di dekat sungai akibat ancaman aliran lahar dingin saat terjadinya hujan. Mengenai tanda-tanda terjadinya erupsi yaitu terjadinya fenomena binatang turun gunung, suara gemuruh dari arah gunung, dan bau pengit atau bau menusuk asap belerang.

\section{Sisi kepercayaan niskala}

Masyarakat Karangasem masih memegang kokoh tradisi terutama yang berkaitan dengan hal niskala. Masyarakat selalu menghubungkan suatu kejadian dengan analisis niskala. Dalam hal tanda-tanda erupsi gunung
Agung misalnya, masyarakat menganggap suara gemuruh dari arah gunung adalah seperti pertanda bahwa dewa yang berstana di gunung Agung membunyikan gamelan pengantar pemargi atau perjalanannya keluar (erupsi). Fenomena binatang turun gunung juga menjadi pertanda bahwa binatang tersebut memberi petunjuk secara niskala kepada masyarakat bahwa akan terjadi sesuatu hal yang kurang baik. Terjadinya erupsi gunung Agung adalah suatu bentuk pembersihan diri dari cuntaka. Selain itu, masyarakat juga memiliki prediksi bahwa letusan gunung Agung akan terjadi pada hari tertentu (dewasa ayu). Bahkan masyarakat sekitar penulis (Abang) memprediksi gunung Agung meletus setelah anak gunung (okan betara) selesai odalan yaitu di Pura Bukit Kanginan yang periode odalannya dari tanggal 5 sampai 10 Oktober.

\section{Sisi langkah pencegahan bencana \\ Masyarakat di sekitar gunung} Agung membuat suatu awig-awig atau peraturan adat tentang segala bentuk pantangan yang harus dipatuhi bagi para pendaki demi terjaganya kesucian pura. Hal ini diantaranya tidak boleh berkata sembarangan, harus berpikir positif, tidak boleh mendaki dalam keadaan sedang haid atau datang bulan, dan tidak membuang sampah sembarangan. Masyarakat berupaya semaksimal mungkin 
menjaga kesucian pura untuk mencegah terjadinya bencana. Selain itu, masyarakat Karangasem juga rutin melakukan upacara ngaturang pekelem atau yadnya setiap tahunnya sebagai wujud pencegahan terjadinya bencana. Serta, setiap akan terjadinya bencana apapun bentuknya masyarakat pasti mengadakan upacara persembahyangan bersama di masing-masing desa yang sering disebut maayu-ayu sebagai wujud permohonan kepada Tuhan agar bencana tidak terjadi dan memohon keselamatan.

\section{Sisi sarana komunikasi tradisional.}

Pada saat terjadinya gempa terutama di malam hari, masyarakat secara reflek berteriak "idup-idup" hal ini dipercaya akan mencegah terjadinya gempa susulan secara niskala. Sebenarnya hal ini sangat bermanfaat sebagai alarm bagi masyarakat lainnya untuk terjaga dan waspada. Selain itu, kulkul bulus atau ketukan kentongan dengan frekuensi cepat, juga selama ini biasanya digunakan sebagai kode bahwa sedang ada bahaya yang terjadi di desa, misalnya kebakaran.

Persepsi dan Komunikasi Masyarakat dalam Bencana Gunung Agung

Berdasarkan hasil wawancara dengan tokoh masyarakat, masyarakat saksi letusan gunung Agung pada tahun 1963, masyarakat terdampak, dan para pengungsi, pada hari Rabu 27
September 2017, dan Kamis 28 September 2017, beserta informasi dari berbagai sumber dapat diketahui bahwa masyarakat memiliki persepsi yang bervariasi tentang bencana gunung Agung. Secara garis besar persepsi masyarakat dapat dibagi menjadi dua sebagai berikut.

\section{Persepsi masyarakat terhadap bencana Gunung Agung}

Pandangan masyarakat mengenai bencana gunung Agung bervariasi. Sebagian masyarakat berpersepsi bahwa daerah tempat tinggal mereka masih aman sehingga mereka memilih untuk tetap tinggal dan tidak mengungsi, meskipun daerah mereka masuk kedalam zona bahaya atau dapat dikatakan masuk kedalam KRB III dan KRB II. Alasan kuat mereka untuk tetap tinggal dan merasa aman adalah acuan sejarah erupsi Gunung Agung pada tahun 1963, menurut pengalaman orangtua/masyarakat yang menjadi saksi erupsi pada tahun 1963 daerah mereka hanya terkena abu vulkanik saja. Sebaliknya, terdapat pula masyarakat yang berpersepsi bahwa daerah mereka tidak aman dan merasa cemas karena adanya gempa terus menerus, sehingga mereka memilih untuk mengungsi ketempat yang mereka anggap aman walaupun mereka berada pada KRB I dan bahkan ada yang berasal dari zona aman. Sementara itu, menurut berita Metro TV, Bali TV (5-6 Oktober 2017) masyarakat di 
pengungsian ada yang sudah meminta pulang ke rumah karena ingin bekerja walaupun daerahnya masih belum aman, sebaliknya masih banyak yang belum berani pulang ke rumahnya walaupun pemerintah sudah menyatakan bahwa daerahnya aman, karena khawatir letusan yang terjadi tibatiba dan dalam skala yang besar di luar prediksi PVMBG.

\section{Persepsi masyarakat terhadap upaya mitigasi yang telah dilakukan pemerintah}

Dalam upaya mitigasi yang telah dilakukan oleh pemerintah, masyarakat berpersepsi bahwa pemerintah sudah melakukan tindakan yang cukup baik. Petugas PVMBG dan BPBN serta aparat telah bekerja keras dalam mengatur lokasi pengungsian, alat transportasi, jalannya proses evakuasi, bahkan begitu besarnya dedikasi pemerintah untuk tetap berjaga menjalankan tugas melakukan pemantauan aktivitas gunung Agung dan patroli di daerah rawan demi menjaga keamanan masyarakat. Fasilitas dan pelayanan serta bantuan yang diberikan di poskoposko pengungsian sangat membantu masyarakat Karangasem. Namun, tidak dapat dipungkiri kurangnya sosialisasi pemerintah kepada masyarakat sejak dini tentang bahaya bencana, kawasan rawan bencana, dan langkah yang harus dilakukan pada level waspada-siaga-awas,

menyebabkan terjadinya kebingungan dan kepanikan dimasyarakat. Komunikasi antara pemerintah dan masyarakat kurang optimal sehingga memicu masuknya berita yang tidak jelas kebenarannya (hoax). Sistem komunikasi masih berjalan dari mulut ke mulut dan terkadang informasi yang tersebar salah. $\mathrm{Hal}$ ini membuat beragam persepsi, prasangka, dan lemahnya kepercayaan.

Optimalisasi Komunikasi Berbasis Kearifan Menyama Beraya dengan Sangkulus dalam Mitigasi Bencana Gunung Agung Menyama beraya adalah suatu istilah untuk menunjukkann pola perilaku masyarakat di Bali yang berkaitan dengan cara berinteraksi, berkomunikasi, dan menyelesaikan suatu permasalahan secara bersamasama. Sistem menyama beraya atau hidup bermasyarakat telah diterapkan dari generasi ke generasi dan menjadi kearifan lokal yang sangat berharga nilainya. Keberadaan pola hidup menyama beraya di dalam kehidupan masyarakat di Karangasem pada khususnya, dan Bali pada umumnya, sangat mendukung pola komunikasi di masyarakat. Kearifan menyama beraya memberikan kekuatan bagi masyarakat untuk menyelesaikan masalah secara mandiri, tidak senantiasa bergantung pada pemerintah. Adapun uraian sistem komunikasi dalam konsep menyama beraya pada masyarakat Karangasem, diantaranya meliputi, pemanfaatan musyawarah untuk mufakat dalam wujud sangkep atau rapat adat, (2) keterlibatan 
tokoh masyarakat yang disegani seperti kelian desa, kelian banjar, kelian dadia, dan tokoh agama, (3) penyampaian informasi dengan komunikasi langsung, pemilihan bahasa alus singgih dalam penyampaian informasi sehingga mudah dimengerti, dan (4) alat komunikasi tradisional misalnya kulkul sebagai wahana mengumpulkan warga.

Dalam hal penyampaian informasi dari pemerintah ke masyarakat berkaitan dengan bencana erupsi gunung Agung, sistem komunikasi berbasis konsep menyama beraya sangat efektif digunakan agar komunikasi terjalin dengan baik dan informasi dapat menyebar ke seluruh lapisan masyarakat tanpa terkecuali. Adapun langkah konkrit optimalisasi komunikasi dengan konsep menyama beraya dengan sangkulus dapat diuraikan sebagai berikut.

Pertama, Level Waspada, informasi bersumber dari pemerintah pusat masuk ke tokoh masyarakat setiap desa. Para ahli vulkanologi mendiskusikan status gunung Agung, kawasan rawan bencana, lokasi dan alur persiapan evakuasi dengan BPBN dan pemerintah Karangasem. Pemerintah memilih petugas yang bergerak ke tiap kecamatan. Pemerintah kecamatan mengumpulkan setiap kepala desa dan ketua sekeha teruna teruni / pemuda untuk diberikan materi sosialisasi. Dari ketua desa, informasi masuk ke masing-masing kelian dadia melalui sangkep atau rapat adat, untuk penetapan batasan dan strategi sosialisasi. Jika alur yang diikuti sesuai dan para tokoh masyarakat cepat tanggap maka upaya penyaluran informasi dari pusat hingga pengadaan sangkep di masing-masing desa hanya memerlukan waktu maksimal tiga hari.

Kedua, Level Siaga, sosialisasi oleh kelian dadia bersama sekeha teruna yang dianggap memiliki cukup ilmu geografi atau paham materi sosialisasi, menggunakan sistem ngatag atau langsung datang ke rumah-rumah. Sosialisasi menggunakan pendekatan merakyat yaitu penjelasan dengan bahasa daerah, dan pemilihan istilah-istilah yang mudah dipahami masyarakat. Disosialisasikan pula pemanfaatan kulkul bulus akan dioptimalkan saat terjadinya bencana. Kegiatan ngatag oleh kelian dadia, seperti yang sudah sering dilakukan dalam masyarakat memerlukan waktu paling banyak dua hari.

Ketiga, Level Awas, masyarakat mengikuti alur mitigasi sesuai dengan apa yang telah disepakati dan disosialisasikan. Saat terjadinya bencana, masyarakat yang bertugas (di luar zona 12 $\mathrm{km}$ ) membunyikan alat komunikasi tradisional kulkul bulus, pada saat ini warga sudah mengetahui apa yang harus dilakukannya sesuai arahan yang telah disepakati.

Adapun keunggulan optimalisasi komunikasi berbasis kearifan menyama beraya dalam upaya mitigasi bencana erupsi gunung Agung yaitu sebagai berikut. 
Bagi masyarakat Karangasem

- Mendapat pengetahuan tentang bencana erupsi dari sumber yang terpercaya

- Lebih memahami maksud dan tujuan upaya mitigasi dari pemerintah karena dijelaskan secara detail dan menggunakan bahasa serta alat yang merakyat

- Mengetahui langkah yang harus diambil untuk antisipasi bencana

- Tidak kebingungan dan tidak mudah diprovokasi

- Lebih siap mental

- Peluang untuk selamat lebih besar (resiko bencana berkurang)

- Konsep menyama beraya semakin erat

\section{Bagi pemerintah Karangasem}

- Memudahkan penyampaian informasi ke masyarakat

- Memudahkan alur mitigasi bencana

- Lebih dipercaya masyarakat

- Mengurangi resiko bencana

\section{PENUTUP}

\section{Simpulan}

Berdasarkan pembahasan di atas, penulis simpulkan sebagai berikut.

1. Gunung Agung terletak di Kecamatan Rendang, Kabupaten Karangasem, merupakan gunung tertinggi di Bali dengan ketinggian 3142 mdpl. Gunung Agung tergolong gunung api tipe stratovulcano berbentuk kerucut dengan kawah memanjang terbuka berukuran $625 \mathrm{~m} \times 425$ m. Gunung Agung adalah gunung api aktif yang memiliki letusan tipe eksplosif dimana berdasarkan sejarah, gunung ini pernah meletus sebanyak empat kali yaitu tahun 1808, 1821, 1843, dan letusan paling dahsyat tahun 1963 yang mengakibatkan 1.148 jiwa meninggal dunia dan 296 luka-luka. Tahun 2017, gunung Agung menggeliat kembali dan memiliki peluang erupsi kembali sejak ditetapkan level AWAS, tanggal 22 September 2017.

2. Masyarakat Karangasem memiliki kearifan lokal terkait dengan bencana erupsi gunung Agung dilihat dari empat sisi, yaitu (1) dari sisi pengetahuan, masyarakat memiliki pengetahuan tentang gejala, dampak, dan kawasan rawan bencana berdasarkan cerita orang tua tentang sejarah letusan tahun 1963, (2) dari sisi kepercayaan niskala, masyarakat memiliki kepercayaan tentang turunnya binatang gunung sebagai pemberi petunjuk niskala akan adanya marabahaya, erupsi gunung Agung adalah suatu bentuk pembersihan diri dari cuntaka, (3) dari segi langkah pencegahan bencana, masyarakat sekitar gunung membuat suatu aturan bagi para pendaki demi menjaga kesucian pura, selain itu, upacara ngaturang pakelem yang rutin dilakukan setiap tahun juga menjadi upaya pencegahan bencana oleh masyarakat, (4) dari sisi komunikasi tradisional, masyarakat memiliki sistem kulkul bulus sebagai penanda terjadinya bahaya. 
$\begin{array}{lrr}\text { 3. Persepsi } & \text { masyarakat } \\ \text { terhadap bencana } & \text { beraneka } \\ \text { ragam terutama } & \text { mengenai } \\ \text { kondisi keamanan } & \text { tempat } \\ \text { tinggalnya dan } & \text { kebijakan }\end{array}$ pemerintah. Terdapat masyarakat yang berpatokan pada sejarah tahun 1963, dan sebagian masyarakat mengikuti instruksi pemerintah saja. Namun, sistem komunikasi antara masyarakat dengan pemerintah belum berjalan dengan optimal sehingga tingkat kekhawatiran tentang ancaman bencana cukup tinggi, dan terdapat kebingungan dalam menentukan langkah mitigasi.

4. Optimalisasi komunikasi berbasis kearifan lokal dalam upaya mitigasi bencana erupsi gunung Agung dapat ditinjau dari tiga (3) sistem komunikasi yang disebut sangkulus, yaitu (1) Sangkep, segala bentuk informasi dan tindakan yang akan diberikan kepada masyarakat sebaiknya didahului dengan rapat adat atau sangkep agar program nantinya mudah diterima oleh masyarakat, (2) Ngatag, informasi dari tokoh masyarakat (kelian dadia) disalurkan ke masyarakat dengan sistem tatap muka langsung ke rumah-rumah, demi meningkatkan kejelasan dan pemahaman dengan penggunaan bahasa mudah dimengerti, (3) Kulkul Bulus, pengaktifan kembali sistem komunikasi tradisional kulkul bulus sebagai penanda terjadinya erupsi gunung Agung dapat membantu memudahkan pengambilan langkah darurat saat terjadinya bencana.

\section{Saran}

Berikut ini saran yang dapat penulis ajukan, diantaranya :

1. Bagi pemerintah, pemerintah hendaknya menerapkan sistem komunikasi berbasis kearifan lokal menyama beraya dengan mempertimbangkan konsep sangkulus, agar komunikasi berjalan optimal dan mitigasi berlangsung lancar.

2. Bagi masyarakat Karangasem, dengan pelaksanaan komunikasi berbasis kearifan lokal, masyarakat sebaiknya lebih membuka pemikiran untuk bekerja sama dan mendukung upaya mitigasi yang dilakukan pemerintah.

3. Bagi sekolah, hendaknya sistem sangkep dapat diadaptasi oleh tokoh masyarakat sekolah untuk membentuk kesepahaman persepsi dengan seluruh warga sekolah dan sistem ngatag dapat diadaptasi untuk memberikan informasi mendetail ke kelaskelas mengenai langkah antisipasi yang perlu disiapkan agar tidak terdapat kendala saat dan setelah terjadi bencana.

\section{DAFTAR PUSTAKA}

Artikelsiana.com, 2014. Pengertian Mitigasi dan Penanganan. Artikel. Tersedia pada http://www.artikelsiana.co $\mathrm{m} / 2014 / 12 /$ pengertianmitigasi-tahappenanganan.html. Diakses pada tanggal 27 September 2017. 
Detik.com, 2017. 6 Potensi Bencana Jika Gunung Agung Meletus Menurut PVMBG. Artikel. Tersedia pada

https://news.detik.com/beri ta/d-3654701/6-potensi-

bencana-jika-gunungagung-meletus-menurutpvmbg.detiknew.6.

Diakses pada tanggal 30 September 2017.

Junaedi, dkk. 2015. Mitigasi Bencana Berbasis Kearifan Lokal Dan Pemanfaatan Teknologi Geografi Untuk Pemetaan Persebaran Permukiman Pada Daerah Rawan Longsorlahan Di Kecamatan Pekuncen Kabupaten Banyumas. Prosiding Seminar Nasional Pendidikan Geografi FKIP UMP 2015 ISBN 978-602-74194-0-7. Purwokerto, 13 Juni 2015. Kompas.com., 2017. BPNP Puji Respon Masyarakat Bali Hadapi Bencana Erupsi Gunung Agung. Artikel. Tersedia pada http://nasional.kompas.co $\mathrm{m} / \mathrm{read} / 2017 / 09 / 25 / 224855$ 31. Diakses pada tanggal 27 September 2017.

Kusumadinata, K., 1979. Data Dasar Gunung api Indonesia. Dit. Vulk., Bandung.

Lestari, Puji.dkk., Komunikasi Lingkungan Untuk Mitigasi Bencana Erupsi Gunung Sinabung. Jurnal. Jurnal ASPIKOM, Volume 3
Nomor 1, Juli 2016, hlm 56-64

Maknun, Johar. Pembelajaran Mitigasi Bencana Berorientasi Kearifan Lokal pada Pelajaran IPA di Sekolah Menengah Kejuruan. Jurnal. Jurnal Kajian Pendidikan, 5(2) Desember 2015.

Martono, Joko. 2015. Mitigasi Bencana Dalam Perspektif Komunikasi Berkearifan Lokal. Artikel. Tersedia pada

Kompasiana.com.htm diakses pada tanggal 21 September 2017.

Merdeka.com, 2017. Tanda Ilmiah dan Tanda Alam Gunung Agung Akan Meletus. Artikel. Tersedia pada

https://www.merdeka.com/ peristiwa/tanda-ilmiah-dantanda-alam-gunungagung-akan-meletus Diakses pada tanggal 27 September 2017.

Nusabali.com., 2017. Gunung Agung Naik Level Awas. Artikel. Tersedia pada http://www.nusabali.com/b erita/19200/gunung-agungnaik-status-awas. Diakses pada tanggal 25 September 2017.

Okezone.com, 2017. Tipe Erupsi Eksplosif, Ini Proses Letusan Gunung Agung saat 1963. Artikel. Tersedia pada https://news.okezone.com/ $\mathrm{read} / 2017 / 09 / 24 / 340 / 1782$ 023/tipe-erupsi-eksplosifini-proses-letusan-gunung- 
agung-saat-1963. Diakses pada tanggal 27 September 2017.

Pratomo, Indiyo. 2006. Klasifikasi Gunung Api Aktif Indonesia, Studi Kasus Dari Beberapa Letusan Gunung Api Dalam Sejarah. Jurnal Geologi Indonesia, Vol. 1 No. 4 Desember 2006: 209-227

Purwantari, BI. 2011. Kearifan Lokal Masyarakat di Sekitar Gunung Agung. Litbang Kompas. Tersedia pada

http://nasional.kompas.co $\mathrm{m} / \mathrm{read} / 2011 / 12 / 19 / 154835$ 12/Kearifan.Lokal.di.Sekita r.Gunung.Agung. Diakses pada tanggal 21 September 2017

Republika.com, 2017. Sejarah Kelam Letusan Gunung Agung 1963. Artikel. Tersedia pada http://nasional.republika.co .id/berita/nasional/daerah/1 7/09/25/owthyn330sejarah-kelam-letusangunung-agung-1963.

Diakses pada tanggal 27 September 2017.

Rukminto, Endrik. 2014. Tentang Pengertian Kearifan Lokal. Artikel. Tersedia pada http://kubuskecil.blogspot.c o.id/2014/02/pengertiankearifan-lokal.html.

Diakses pada tanggal 28 September 2017.

Rumata, Nini Apriani. 2012. Pengertian Mitigasi Bencana. Artikel. Tersedia pada http://euforiaagain.blogspot.co.id/2012/ 10/mitigasi-bencana.html.

Diakses pada tanggal 27 September 2017.

Sadguna, I Gede Made Indra. 2010. Kulkul Sebagai Simbol Budaya Masyarakat Bali. Makalah. Tersedia pada http://blog.isi-

dps.ac.id/indrasadguna/?p $=22$. Diakses pada tanggal 30 September 2017.

Sunarti, Vevi. 2017. Peranan Pendamping Desa Dalam Membentuk Masyarakat Sadar Bencana Sebagai Salah Satu Mitigasi Bencana. Prosiding Seminar Nasional Jurusan Pendidikan Luar Sekolah Fakultas Pendidikan Universitan Negeri Padang.

Wardyaningrum, Damayanti. $2010 . \quad$ Perubahan Komunikasi Masyarakat Dalam Inovasi Mitigasi Bencana Di Wilayah Rawan Bencana Gunung Merapi. Jurnal ASPIKOM, Volume 2 Nomor 3, Juli 2014, hlm 179-197.

Wikipedia.com, 2017. Gunung Agung - Wikipedia bahasa Indonesia, ensiklopedia bebas. Artikel. Tersedia pada

https://id.wikipedia.org/wiki /Gunung_Agung. Diakses pada tanggal 27 September 2017. 